\title{
Comparison between the Brix Refractometer and ELISA for Assessment of Colostrum IgG of Montbeliard x Holstein Cross Dairy Cows
}

\author{
N. H. Fahima,* \& T. A. Imbabi ${ }^{b}$ \\ ${ }^{a}$ Animal Production Department, Faculty of Agriculture, Cairo University, Giza, Egypt \\ ${ }^{b}$ Animal Production Department, Faculty of Agriculture, Benha University, Moshtohor, Egypt \\ "Corresponding author: nadiaamn@agr.cu.edu.eg \\ (Received 19-11-2020; Revised 24-02-2021; Accepted 01-03-2021)
}

\begin{abstract}
The objectives of the present study were to examine the association between the brix refractometer\% and ELISA assays in the assessment of colostrum-IgG content and in studying the factors affecting this content. Contents of IgG in colostrum samples of 132 healthy primiparous and multiparous Montbeliard $x$ Holstein cross dairy cows kept in Egypt were evaluated using ELISA assay and brix refractometer\%. The ELISA results showed that the IgG contents in the colostrum samples ranged from 5.96 to $114.84 \mathrm{mg} / \mathrm{mL}$, with a mean of $57.07 \mathrm{mg} / \mathrm{mL}$. Brix \% results ranged from $15 \%$ to $35 \%$, with a mean of $23.97 \%$. The correlation and regression coefficients between ELISA(IgG) and brix $\%$ were significantly high $\left(\mathrm{r}=0.68\right.$ and $\mathrm{r}^{2}=0.59$, respectively). Prediction regression equation was ELISA(IgG) $=31.81+1.12($ brix refractometer $\%)$. The effects of parity and season of calving on both ELISA(IgG) and brix \% were significant. ELISA(IgG) and brix $\%$ were higher in cows $\geq 3$ lactations than those in the first and second lactations. Moreover, summer calving recorded higher ELISA(IgG) and brix \% than autumn calving. Either ELISA(IgG) or brix $\%$ were not significantly affected by calf's sex, single/twin births, or history of cows' diseases. ELISA(IgG) and brix \% had a significant positive correlation with calf's birth weights and gestation lengths, while they recorded a non-significant correlation with dry-period length. It can be concluded that a refractometer is a simple on-farm tool to assess colostrum quality. Its high correlation with the lab analytical assay of ELISA confirms the validity of using refractometers by researchers in colostrum studies.
\end{abstract}

Keywords: refractometer; colostrum; IgG; Montbeliard $x$ Holstein

\section{INTRODUCTION}

Colostrum is the first secretion obtained from the mammary gland postpartum. Colostrum with sufficient good quality should be provided to the newborn calves. Calves offered colostrum with inadequate quality are highly exposed to the risk of mortality and morbidity throughout the pre-weaning period. Moreover, this deficiency could be negatively reflected in the subsequent stages of calves' future life. The quality of colostrum is interrelated with its Ig content. Three kinds of Ig exist in colostrum; IgG, IgM, and IgA (Geiger, 2020). IgG represents more than $85 \%$ of the total immunoglobulin (Turini et al., 2020). The concentration of IgG in colostrum is variable according to breed, lactation number, prepartum diet, calving season, dry period length, vaccination of the cow, and time of sample collection (Silva-Del-Río et al., 2017; Sutter et al., 2019). It has been reported that $30-50 \%$ of the colostrum contains insufficient amounts of IgG (Morrill et al., 2012; Bartier et al., 2015). Besides, in some cases, the mother cow could not produce sufficient amounts of colostrum or produce low-quality colostrum. Therefore, dairy farms usually store the excess colostrum by freezing it to be used later. All of these matters emphasize the necessity to assess the colostrum quality before feeding the newborn calves and before storage. The mainly accepted methods for quantifying the colostrum $\operatorname{IgG}$ concentration are RID and ELISA (Gross et al., 2014). Both methods are performed in the laboratory. They include many steps that need specific requirements and take time. Therefore, they are not suited for practical colostrum-quality control at the farm. On-farm tools for evaluating colostrum quality are urgently needed. Using color intensity or viscosity of colostrum to assess its quality is not an accurate method because there was no correlation was established between the color intensity or viscosity of colostrum and IgG concentration (Gross et al., 2014). Besides, the colostrometer depends on measuring specific gravity. However, specific gravity is greatly related to protein concentration than IgG concentration. Additionally, their breakability and sensitivity to temperature have restricted their adoptions on the farm (Quigley et al., 2013). Brix has recently been acceptable. In comparison to a colostrometer, refractometers are easier to use, and smaller samples are needed, lower temperature dependence (Bielmann et al., 2010), and the high correlation to direct-estimation methods of IgG has been found (Bartier et al., 2015), it is around 0.6-0.7 (Buczinski \& Vandeweerd, 2016). The refractometer has been used to measure the brix $\%$ of a solution. The Brix scale is used to indicate the sugar content of a solution, 
but this scale has been modified for on-farm use in dairy farms. Brix of $22 \%$ is the appropriate identification of good-quality colostrum in dairy cattle (Bielmann et al., 2010). Assessment of IgG content of colostrum immediately after calving cannot easily be done on-farm by direct methods. Therefore, brix refractometry can be used to estimate the total solids concentrations in colostrum indirectly by quantifying the refractive index of the solution (Buczinski \& Vandeweerd, 2016). In Egypt, most dairy farms, if not all, do not evaluate the colostrum. The majority of them just discard the colostrum of heifers and use the colostrum of older cows either fresh or frozen. Some farms use calf colostrum replacers to avoid low-quality colostrum. The use of colostrum replacer adds extra economic burdens on farms. Although refractometers are cheap and easy to buy and use, they have not been used by any farm in Egypt. Moreover, the validity of refractometers to assess the colostrum quality of Montbeliard x Holstein cross dairy cows had not been examined. Therefore, the objectives of this study were to (1) establish the level of relationship between ELISA values (as the reference method) and the brix refractometer\% (as an on-farm tool) for measuring the IgG concentration of colostrum in Montbeliard $x$ Holstein cross dairy cows raised in Egypt and (2) to examine the validity to use brix in colostrum studies to replace laboratory assays by studying the factors affecting colostrum quality by the two methods of brix and ELISA and compare the trends of their results.

\section{MATERIALS AND METHODS}

\section{Colostrum Sampling}

The composite of first colostrum samples was collected from 132 Montbeliard x Holstein cross cows (50\% Holstein and 50\% Montbeliard) kept in a commercial dairy farm in the West of Egypt. The samples were taken from healthy udders' quarters for cows calved from June to October 2019. In total, 35\% of the cows enrolled were the first-parity cows, $26 \%$ were the second-parity cows, and $39 \%$ were cows of the third-parity or more. Colostrum samples were collected into $50-\mathrm{mL}$ plastic tubes labeled with cow numbers. Samples were stored at $-20^{\circ} \mathrm{C}$ until $\mathrm{IgG}$ assessment. Data belonged to sampled cows were got from the herd management software Dairy Comp 305 (Valley Ag Software, Tulare, CA).

\section{ELISA Assay}

The IgG concentration of the colostrum was determined using the bovine IgG ELISA quantitation set (catalog no. SG-60224 of Sino Gene Con Biotech Co., Ltd). The colostrum samples were prepared first to be ready for the ELISA assay. Colostrum samples were thawed at room temperature. About $10 \mathrm{~mL}$ of each colostrum sample was put into the centrifuge. $10 \mathrm{~mL}$ of ethyl acetate was added to the samples and centrifuged for $4000 \mathrm{X} \mathrm{g}$ for 10 minutes. Then $1 \mathrm{~mL}$ of ethyl acetate layer was put in another tube and evaporated under $60^{\circ} \mathrm{C}$ nitrogen. The residues were dissolved in a $2 \mathrm{~mL}$ buffer. Purified IgG antibody was adopted to coat microtiter plate to make solid-phase antibody. Then IgG was added to the wells. IgG antibody was combined with horseradish peroxidase to form the antibodyantigen-enzyme-antibody complex. After completing washing, tetramethylbenzidine was added as a soluble substrate. When tetramethyl benzidine became blue color at the catalysis of horseradish-peroxidase enzyme, a stop solution was added to stop the reaction. The color change was measured at a wavelength of $450 \mathrm{~nm}$. The concentration of IgG in the samples was determined from the calibration curve of the absorbance values obtained for the standards.

\section{Brix\% Measurement}

Brix\% was measured by an optical refractometer with a scale from 0 to $35 \%$. Samples with values exceeded $35 \%$ were assigned a value of $35 \%$. The optical apparatus was read by the same one. One drop of colostrum was picked from the thawed plastic tube by a small pipette. The cover plate of the device was pressed down to spread the sample over the prism. The refractometer was moved towards a light source and look through the eyepiece. The lens was rotated while looking at it until the meter is in focus. Pressing down is kept on the cover plate while looking through the lens and reading the level between the blue and white sections. This is brix's reading of the sample. The prism was cleaned with distilled water and dried with tissue paper in between samples.

\section{Data Analysis}

Data were statistically analyzed using SAS 9.2. The Univariate procedure was performed to estimate the frequencies and descriptive statistics of the observations. The correlation procedure was used to determine the level of the relationship between the ELISA(IgG) and brix $\%$. Correlations among calf's birth weight, gestation length, and dry period length with both ELISA(IgG) and brix $\%$ were also performed. Moreover, the regression procedure was used to develop a prediction equation to estimate the IgG concentration from brix\%. The effects of parity, calving season, calf's sex, single/twin births, and history of cows' diseases on ELISA(IgG) and brix \% were evaluated using ANOVA and the least-square method. The least-squares means were compared, and significance was stated at $\mathrm{p}<0.05$.

\section{RESULTS}

The results of ELISA(IgG) measurements ranged from 5.96 to $104.84 \mathrm{mg} / \mathrm{mL}$ with a mean of $57.07 \mathrm{mg} /$ $\mathrm{ml}$, whereas brix \% ranged from 15 to $35 \%$ with a mean of $23.97 \%$ (Table 1). ELISA(IgG) results showed that almost $21 \%$ of colostrum samples had IgG concentrations less than $50 \mathrm{mg} / \mathrm{mL}$ (Figure 1). Furthermore, brix \% showed that $23 \%$ of samples had less than $18 \%$ (Figure 2). Figures of $50 \mathrm{mg} / \mathrm{mL} \mathrm{IgG} \mathrm{and} 18 \%$ of brix are the minimum levels in which the concentration of immune bodies in colostrum should not be lower. Pearson's correlation coefficients are presented in Table 2. Results showed that ELISA(IgG) and brix\% were positively correlated $(r=0.68)$. The association was significant 
$(p<0.0001$, Figure 3$)$. The regression of ELISA(IgG) by brix refractometer $\%$ was strong and significant $\left(\mathrm{r}^{2}=\right.$ $0.59, \mathrm{p}<0.0001)$. The prediction equation of ELISA(IgG) by brix refractometer\% was presented in Figure 4 . Both ELISA(IgG) and brix (\%) recorded a significant positive correlation with calf's birth weight $(p<0.0190$ and $\mathrm{p}<0.0001$, respectively) and gestation length $(\mathrm{p}<0.0230$ and $\mathrm{p}<0.0001$, respectively). However, they recorded a non-significant positive correlation with dry period length. Results of factors affecting ELISA(IgG) and brix (\%) were shown in Table 3. ELISA(IgG) was significantly affected by parity and season of calving $(\mathrm{p}<0.0001$ and $\mathrm{p}<0.0301$, respectively). The same effect of parity and season of calving was recorded with brix $\%(p<0.0001$ and $p<0.0186$, respectively). The effects of calf's sex and single/twin births were insignificant. Lameness, abortion, and mastitis were the most frequent diseases recorded for some cows enrolled in the present study. No significant association was found between these diseases and both ELISA(IgG) and brix \%. But there was a trend

Table 1. Descriptive statistics for 132 Montbeliard x Holstein cross dairy cows enrolled in a study to evaluate colostral IgG content

\begin{tabular}{lcccc}
\hline \multicolumn{1}{c}{ Variables } & Mean & SD & Minimum & Maximum \\
\hline ELISA (IgG, mg/mL) & 57.07 & 21.96 & 5.96 & 114.84 \\
Brix (\%) & 23.97 & 5.26 & 15.00 & 35.00 \\
Calf's birth & 32 & 3.52 & 19 & 49 \\
weight(kg) & & & & \\
Gestation length (d) & 274 & 4.72 & 270 & 286 \\
Dry period length (d) & 60.73 & 4.65 & 53 & 71 \\
\hline
\end{tabular}

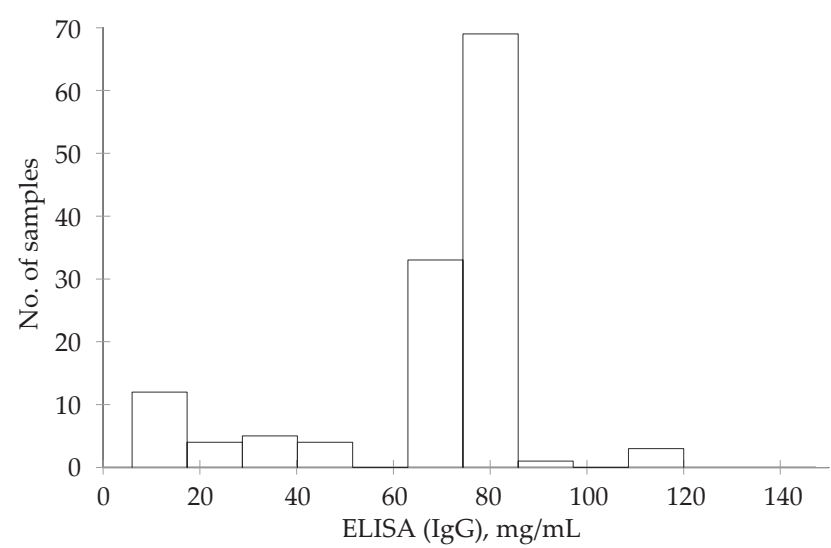

Figure 1. Frequency distributions of IgG content measured by enzyme-linked immunosorbent assay (ELISA) for 132 Monbilliard X Holstein cross dairy cows colostral samples. of a decrease of ELISA(IgG), and brix \% with cows had a history of diseases, namely mastitis.

\section{DISCUSSION}

\section{ELISA(IgG) and Brix\%}

A wide range of IgG resulted in the present study (5.96-114.84 mg/mL). This result was comparable to Kessler et al. (2020a), reporting that ELISA(IgG) ranging from 18.8 to $106.0 \mathrm{mg} / \mathrm{mL}$. The average IgG value of $57.07 \mathrm{mg} / \mathrm{mL}$ resulted in the present study was lower than $94 \mathrm{~g} / \mathrm{L}$ in a study of Holstein dairy cows in Canada (Bielmann et al., 2010), $74.4 \mathrm{~g} / \mathrm{L}$ (Shivley et al., 2018), and $110.5 \mathrm{mg} / \mathrm{mL}$ in German Holstein Friesian (Kessler et al., 2020 b). The IgG average was also lower than the results of $63.7 \mathrm{~g} / \mathrm{L}$ (Bartier et al., 2015) and $68.8 \mathrm{~g} / \mathrm{L}$ (Morrill et al., 2012). However, it was higher than 45.0 $\mathrm{g} / \mathrm{L}$ in a survey including 1,250 colostrum samples in Norway (Gulliksen et al., 2008) and $41.5 \mathrm{~g} / \mathrm{L}$ in 189 colostrum samples from Dutch cows (Verweij et al., 2014). Generally, high-quality colostrum should contain at least $50 \mathrm{mg} / \mathrm{mL}$ of IgG (Gulliksen et al., 2008). The wide range of colostrum IgG concentrations was also reported in many previous studies. Gulliksen et al. (2008) stated that the colostrum IgG content ranged from 4 to $235 \mathrm{~g} / \mathrm{L}$. Baumrucker et al. (2010) reported values of 9 to $166 \mathrm{~g} / \mathrm{L}$ in a US study of 214 cows. This wide range in colostrum IgG refers to the great variation among cows. Moreover, those studies have quantified colostrum $\operatorname{IgG}$ using different laboratory-analysis techniques. Furthermore, differences in sample preparation between studies also

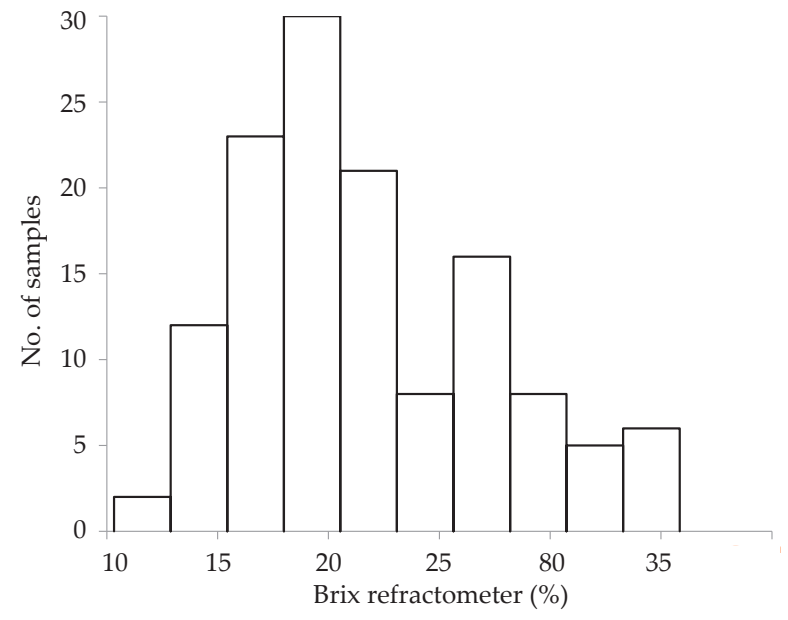

Figure 2. Frequency distributions of indirect IgG assessment by brix refractometer\% for 132 Monbilliard X Holstein cross dairy cows colostral samples.

Table 2. Correlation coefficient analysis among clostoral IgG content (ELISA and Brix \%) and calf's birth weight, gestation length, dry period length in Montbeliard x Holstein cross dairy cows

\begin{tabular}{lcccc}
\hline \multicolumn{1}{c}{ Variables } & Brix $\%$ & calf's birth weight & Gestation length & Dry period length \\
\hline ELISA(IgG) & $\mathrm{r}=0.68$ & $\mathrm{r}=0.25$ & $\mathrm{r}=0.24$ & $\mathrm{r}=0.12$ \\
& $\mathrm{p}=0.0001$ & $\mathrm{p}=0.0190$ & $\mathrm{p}=0.0230$ & $\mathrm{p}=0.3551$ \\
Brix\% & & $\mathrm{r}=0.43$ & $\mathrm{r}=0.45$ & $\mathrm{r}=0.15$ \\
& & $\mathrm{p}=0.0001$ & $\mathrm{p}=0.0001$ & $\mathrm{p}=0.2431$ \\
\hline
\end{tabular}

Note: $\mathrm{p}<0.05$ considered significant, $\mathrm{r}=$ correlation coefficient. 


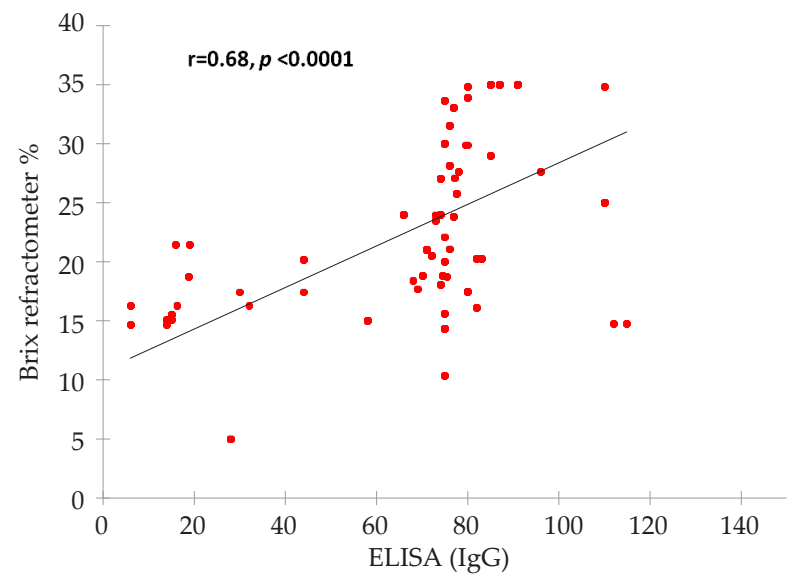

Figure 3. Correlation coefficient between enzyme-linked immunosorbent assay ELISA(IgG) concentration and brix refractometer \% of 132 Monbilliard X Holstein cross dairy cows colostral samples.

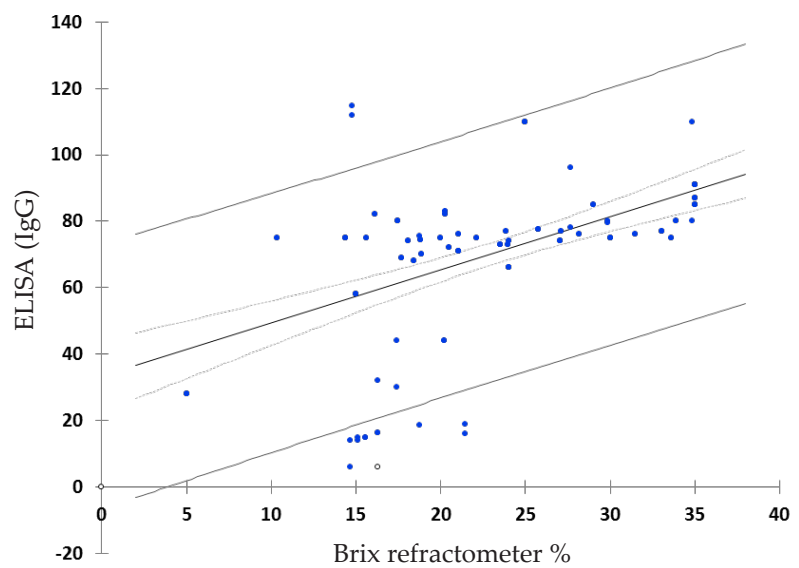

Figure 4. Regression plot between enzyme-linked immunosorbent assay (ELISA)IgG concentration and brix refractometer\% of 132 Monbilliard X Holstein cross dairy cows colostral samples. Regression equation= ELISA $(\operatorname{IgG})=31.81+1.12$ (brix refractometer \%).

Table 3. ELISA(IgG) and Brix \% by parity, the season of calving, calf's sex, single/twin births, and history of cows' diseases in Montbeliard $x$ Holstein cross dairy cows

\begin{tabular}{|c|c|c|c|c|c|c|c|}
\hline \multirow{2}{*}{ Variables } & \multicolumn{4}{|c|}{ ELISA(IgG) } & \multicolumn{3}{|c|}{ Brix \% } \\
\hline & No. & Mean & SE & $\mathrm{P}$-value & Mean & $\mathrm{SE}$ & P-value \\
\hline \multicolumn{8}{|l|}{ Parity } \\
\hline 1 st & $47(35 \%)$ & $47.82^{\mathrm{b}}$ & 10.16 & 0.0003 & $21.59^{b}$ & 0.81 & 0.0001 \\
\hline 2nd & $34(26 \%)$ & $51.01^{\mathrm{b}}$ & 13.33 & & $21.62^{\mathrm{b}}$ & 1.08 & \\
\hline$\geq 3 \mathrm{rd}$ & $51(39 \%)$ & $72.42^{a}$ & 7.12 & & $27.42^{\mathrm{a}}$ & 0.93 & \\
\hline \multicolumn{8}{|l|}{ Season of calving } \\
\hline Summer & $84(64 \%)$ & $64.89^{a}$ & 9.76 & 0.0301 & $25.15^{\mathrm{a}}$ & 0.66 & 0.0186 \\
\hline Autumn & $48(36 \%)$ & $49.25^{\mathrm{b}}$ & 12.02 & & $22.67^{b}$ & 0.89 & \\
\hline \multicolumn{8}{|l|}{ Calf's sex } \\
\hline Male & $55(42 \%)$ & 59.89 & 11.03 & 0.0669 & 24.13 & 0.93 & 0.8237 \\
\hline Female & $77(58 \%)$ & 54.25 & 10.10 & & 23.87 & 0.72 & \\
\hline \multicolumn{8}{|l|}{ Single/twin births } \\
\hline Single & $121(92 \%)$ & 58.69 & 7.64 & 0.1520 & 23.97 & 0.55 & 0.0582 \\
\hline Twins & $11(8 \%)$ & 55.41 & 14.26 & & 27.85 & 1.94 & \\
\hline \multicolumn{8}{|c|}{ History of cows' diseases } \\
\hline Healthy & $75(56.9 \%)$ & 62.01 & 9.83 & 0.3639 & 26.25 & 0.72 & 0.5813 \\
\hline Lameness & $33(25 \%)$ & 58.62 & 10.25 & & 23.99 & 1.09 & \\
\hline Abortion & $11(8.3 \%)$ & 56.12 & 14.12 & & 24.69 & 1.85 & \\
\hline Mastitis & $13(9.8 \%)$ & 51.41 & 12.00 & & 22.98 & 1.75 & \\
\hline
\end{tabular}

Note: Means in the same column with different superscripts differ significantly $(\mathrm{p}<0.05)$.

exist. For example, Baumrucker et al. (2010) removed the colostrum fat before the analysis but Morrill et al. (2012) did not do this protocol. In addition, many studies suggested a wide range of brix $\%$ readings. Brix $\%$ of the present study ranged from $15 \%$ to $35 \%$. This result fell within the range mentioned by Zentrich et al. (2019). They stated that colostrum quality varied between $9.3 \%$ and $42.0 \%$ brix. However, the current brix \% mean is higher than $18.7 \%$ reported by Denholm et al. (2018), studying 281 bovine colostrum samples. The current study showed that more than $20 \%$ of the colostrum samples had a lower percentage of IgG than that recommended for calves. Therefore, it is highly recommended to assess the colostrum quality before feeding calves or storing them in colostrum banks.

\section{Correlation and Regression Coefficients}

The present result of correlation $(r=0.68)$ between ELISA(IgG) and brix \% was lower than 0.86 and 0.89 reported by Morrill et al. (2015) and Hassan et al. (2020), respectively. Furthermore, regression coefficient $\left(r^{2}=\right.$ $0.59)$ was lower than $r^{2}=0.73$ and $r^{2}=0.66$ reported by Bielmann et al. (2010) and Løkke et al. (2016), respectively. However, it was higher than $r^{2}=0.43$ reported by Bartier et al. (2015). The significant strong positive correlation between brix refractometer $\%$ and the direct laboratory analytical assay of ELISA proves that refractometer is acceptable as an on-farm tool for quantitatively evaluating colostrum IgG concentrations. 


\section{Dry Period Length (DPL)}

The association between IgG concentration in colostrum and DPL was discussed in many studies, which included different trends. The result of the present study showed that ELISA(IgG) and brix \% had no significant correlation with DPL. The same result was reported by Genc (2015), Mayasari et al. (2015), Cabral et al. (2016), Kessler et al. (2020a). Besides, no differences were found in colostrum IgG concentration in cows having either a 40- or 60- DPL (Shoshani et al., 2014). On the other hand, Morrow (1976) stated that long dry periods might negatively affect the colostrum IgG, which may lead to obesity and raise the body condition score and weaken the immune system's role to produce adequate antibodies. In addition, Le Cozler et al. (2016) reported a small positive correlation between DPL and colostrum IgG level. Besides, Dunn et al. (2017) found that cows with an 8- to 12- wk dry period could produce greater IgG concentrations in their colostrum than cows with dry periods less than 8 weeks in length. A comparable effect was stated by Cabral et al. (2016) for cows given no dry period or a shorter and longer dry period. Cows given no dry periods produced lower quality colostrum compared with cows given a dry period. In addition, Johnsen et al. (2019); Zentrich et al. (2019) reported that DPL had a significant effect on the quality of the colostrum produced after birth. Therefore, the DPL of dairy cows is thought to be an important environmental factor in terms of the quality of the colostrum produced after birth. However, the optimal DPL in terms of colostrum quality is debatable (Kessler et al., 2020a). As long as the dry period is not completely eliminated, its length seems to be of little relevance in terms of colostrum quality (Dunn et al., 2017; Kessler et al., 2020b).

\section{Calf's Birth Weight}

The present study found a significant positive correlation between ELISA(IgG) and brix \% with birth weight. This result was in agreement with (Berry et al., 2004). They referred to the increase of IgG content with the cow parity (age), and the older cows are expected to provide weightier calves because of the moderate heritability of animal size. Conversely, Kessler et al. (2020a), studying 29 multiparous Holstein cows, revealed that IgG concentration in colostrum was negatively associated with birth weight.

\section{Gestation Period Length (GL)}

A significant positive correlation was found in the current study between ELISA(IgG) and brix \% with GL. This result agreed with Baumrucker et al. (2016). They referred to the positive role of a prolonged period of gestation, which may reflect on the period of colostrogenesis, including colostrum IgG content. Oppositely, a negative association was reported between GL and colostrum IgG content by Kessler et al. (2020a). However, Kessler et al. (2020b) revealed no effect of GL on colostrum composition.
Factors affecting colostrum IgG in Montbeliard x Holstein Cross dairy cows parity. Several studies focused on the effect of parity on colostrum quality. This effect was found to be statistically insignificant by Genc (2015) and Hoyraz et al. (2015). However, in the present study, a significant effect of parity on both ELISA(IgG) and brix $\%$ was found. They increased with the parity number. Primiparous cows recorded the lowest values, and multiparous cows $\geq 3$ lactations recorded the highest ones. Significant effect of parity and increase of IgG concentration with the advance of parity order was also documented by several researchers (Conneely et al., 2013; Cabral et al., 2016; Dunn et al., 2017; Kessler et al., 2020b; Turini et al., 2020). This is because age is the main element affecting immunity where older cows, that are exposed to pathogens and vaccinations for a longer time during their life than younger cows lead to give colostrum with greater antibodies. However, the lowest colostrum quality was observed in the second parity, not the first one (Djoharjani et al., 2019; Johnsen et al., 2019). However, the authors did not give the reasons for that. Besides, Gulliksen et al. (2008) found that some young cows produced very good nutritional and immunological quality colostrum. Therefore, colostrum quality should continuously be assessed before providing to calves to avoid rejecting the colostrum of young cows with sufficient quality (Shivley et al., 2018).

Season of calving. In the present study, ELISA(IgG) and brix $\%$ were significantly higher for cows calved during summer months compared to those calved in the autumn month. While, Gulliksen et al. (2008) reported that cows calved during August, September, and October produced colostrum of higher quality compared with cows calved during the other months. However, Genc (2015) reported that colostrum quality was lower in cows calved in the summer months. Also, Conneely et al. (2013) found that cows calved in autumn had a significantly high IgG concentration compared to those calved in the spring season. This is while Dunn et al. (2017) reported that higher concentrations of IgG were recorded in the winter and IgG content was lowest in the spring and autumn. Moreover, the lowest quality of colostrum was attained during the winter. Gulliksen et al. (2008) reported that the distinct differences in climate among months and seasons lead to differences in the occurrence of disease, feeding availability, environmental temperature, or day length, which may affect the IgG production. Moreover, Gavin et al. (2018) found that colostrum production in multiparous cows was strongly correlated with photoperiod one month before and at calving. This observation would suggest that colostrogenesis is influenced by photoperiod, which differs across different seasons. In the current study, the low level of IgG in colostrum produced in autumn may be returned to the stressful conditions the cow facing during late pregnancy. They spent this period in the summer month when temperatures increased, and the diet components changed, such as the unavailability of Egyptian clover, the main green fodder, as it is available from December and May. 
Calf's sex. In the present study, calf's sex had no significant effect on both ELISA(IgG) and brix\%. This result agrees with Cabral et al. (2016) and Kessler et al. (2020a). On the contrary, Angulo et al. (2015) stated that the calf's sex significantly influenced the IgG content of colostrum. It was higher for males than for females. They attributed that to the dilution effect due to the condition that cows with a female calf produce higher quantities of colostrum than cows with a male calf.

Single/twin births. In the present study, ELISA(IgG) and brix \% were not affected by single/twin births. Twin births are not common in cattle, so studies did not give the care to investigate its association with colostrum quality. Twin births are common in small ruminants. A similar result was revealed by Argüello et al. (2006), reporting no differences in IgG levels with single and multiple litter sizes of ovine colostrum. However, Csapo'et al. (1994) found that IgG content was higher at parturition in twins' ewes and goats than in single (118.4 vs. 98.7 and 132.4 vs. $112.2 \mathrm{mg} / \mathrm{mL}$ of $\mathrm{IgG}$, ewes and goats twin and single birth, respectively.

History of cows' diseases. Some cows enrolled in the present study had a history of diseases of lameness, abortion, and mastitis in the last previous lactation. Although, there were no significant differences among cows that had a history of these diseases compared to the healthy ones concerning their ELISA(IgG) and brix $\%$. There was a trend of a decrease in colostrum quality with these diseases, namely for mastitis. As far as we know, there are no studies available on the association between lameness or abortion with colostrum IgG. But some researchers investigated the effect of mastitis infection on bovine colostrum IgG. However, this effect is not decisively defined, and studies results are conflicting. Denholm et al. (2018) reported no association between clinical mastitis in the previous lactation and colostrum IgG. Conversely, Maunsell et al. (1998) stated that colostrum yield and its IgG content were lower in cows with infected udders than cows with uninfected udders. Moreover, Cabral et al. (2016) referred to the importance of using teat sealants and antibiotics at dry off to avoid mastitis during dry periods, which can diminish colostrum quality. Puppel et al. (2020) concluded that the SCC of the first milking colostrum could be used as an indicator of colostrum quality. They found nearly double the concentration of first colostrum immunoglobulins in cows with SCC $\geq 400,000$ cells $/ \mathrm{mL}$ than in colostrum from cows with SCC $\leq 400,000$ cells/ $\mathrm{mL}$. Generally, it was noticeable that the values of brix $\%$ could give the same trend as the same as ELISA assay significant results such as parity order and season of calving in the current study. However, the factors had non-significant effects such as calf's sex and single/ twin births different trends were obtained. The current study showed that values of brix $\%$ had the same trends of results when studying the factors affecting IgG concentration.

\section{CONCLUSION}

It can be concluded that a refractometer is an acceptable on-farm tool for quantitatively evaluating colostrum IgG concentrations of Montbeliard x Holstein cross dairy cows. Refractometers can also be used by researchers in colostrum studies, and the refractometer brix $\%$ achieved the same trends as the ELISA assay achieved when studying the factors affecting colostrum quality. The highest colostrum IgG content of Montbeliard $x$ Holstein cross dairy cows was scored by multiparous cows $\geq 3$ lactations and by Summer-calving cows. Although, the no significant effect of the history of cow diseases on colostrum IgG content in this study, the trend of decrease of colostrum quality with this factor, particularly for mastitis, needs more researches.

\section{CONFLICT OF INTEREST}

We declare that there is no conflict of interest with any financial, personal, or other relationships with other people or organizations related to the material discussed in the manuscript.

\section{REFERENCES}

Angulo, J., L. Miguel Gómez, L. Mahecha, E. Mejía, J. Henao, \& C. Mesa. 2015. Calf's sex, parity and the hour of harvest after calving affect colostrum quality of dairy cows grazing under high tropical conditions. Trop. Anim. Health. Prod. 47:699-705. https://doi.org/10.1007/s11250-015-0781-z

Argüello, A., N. Castro, S. Álvarez, \& J. Capote. 2006. Effects of the number of lactations and litter size on chemical composition and physical characteristics of goat colostrum. Small Rumin. Res. 64:53-59. https://doi.org/10.1016/j. smallrumres.2005.03.016

Bartier, A. L., M. C. Windeyer, \& L. Doepel. 2015. on-farm tools for colostrum quality measurement. J. Dairy Sci. 98:18781884. https://doi.org/10.3168/jds.2014-8415

Baumrucker, C. R., A. M., Burkett, A. L. Magliaro-Macrina, \& C. D. Dechow. 2010. Colostrogenesis: Mass transfer of immunoglobulin G1 into colostrum. J. Dairy Sci. 93:30313038. https://doi.org/10.3168/jds.2009-2963

Baumrucker, C. R., C. D. Dechow, A. L. Macrina, J. J.Gross, \& R. M. Bruckmaier. 2016. Mammary immunoglobulin transfer rates following prepartum milking. J. Dairy Sci. 99:9254-9262. https://doi.org/10.3168/jds.2016-11370

Berry, D. P., F. Buckley, P. Dillon, R. D. Evans, \& R. F. Veerkamp. 2004. Genetic relationships among linear type traits, milk yield, body weight, fertility and somatic cell count in primiparous dairy cows. Irish J. Agric. Food Res. 43:161-176.

Bielmann, V., J. Gillan, N. R. Perkins, A. L. Skidmore, S. Godden, \& K. E. Leslie. 2010. An evaluation of Brix refractometry instruments for measurement of colostrum quality in dairy cattle. J. Dairy Sci. 93:3713-3721. https:// doi.org/10.3168/jds.2009-2943

Buczinski, S. \& J. M. Vandeweerd. 2016. Diagnostic accuracy of refractometry for assessing bovine colostrum quality: A systematic review and meta-analysis. J. Dairy Sci. 99:73817394. https://doi.org/10.3168/jds.2016-10955

Cabral, R. G., C. E.Chapman, K. M. Aragona, E. Clark, M. Lunak, \& P. S. Erickson. 2016. Predicting colostrum quality from performance in the previous lactation and environmental changes. J. Dairy Sci. 99:4048-4055. https://doi. org/10.3168/jds.2015-9868

Conneely, M. D., P. Berry, R. Sayers, J. P. Murphy, I. Lorenz, 
M. L. Doherty, \& E. Kennedy. 2013. Factors associated with the concentration of immunoglobulin $\mathrm{G}$ in the colostrum of dairy cows. Animal 7:1824-1832. https://doi.org/10.1017/ S1751731113001444

Csapo, J., Z. Csapo, T. G. Martin, J. Szentpeteri, \& G. Wolf. 1994. Composition of colostrum from goats, ewes and cows producing twins. Int. Dairy J. 4:445-458. https://doi. org/10.1016/0958-6946(94)90058-2

Denholm, K. S., S. McDougall, G. Chambers, \& W. Clough. 2018. Factors associated with colostrum quality in individual cows from dairy herds in the Waikato region of New Zealand. N. Z. Vet. J. 66:115-120. https://doi.org/10.1080/004 80169.2017.1418684

Djoharjani, T., A. Ridhowi, \& S. Kemal. 2019. The Effect of Parity on Colostrum Quality of Friesian Holstein Crossbred Cows in Indonesia. IOP Conference Series: Earth and Environmental Science, Vol. 478, The $4^{\text {th }}$ Animal Production International Seminar 24-27 October, Malang, Indonesia. https://doi.org/10.1088/1755-1315/478/1/012058

Dunn, A., A. Ashfield, B. Earley, M. Welsh, A. Gordon, \& S. J. Morrison. 2017. Evaluation of factors associated with immunoglobulin $\mathrm{G}$, fat, protein, and lactose concentrations in bovine colostrum and colostrum management practices in grassland-based dairy systems in Northern Ireland. J. Dairy Sci. 100:2068-2079. https://doi.org/10.3168/jds.2016-11724

Gavin, K., A. Hoffman, J.N. Kiser, M.A.Cornmesser, S. AmirpourHaredasht, B. Martínez-López, J.R. Wenz, \& D.A. Moore. 2018. Low colostrum yield in Jersey cattle and potential risk factors. J. Dairy Sci. 101:6388-6398. https://doi. org/10.3168/jds.2017-14308

Geiger, A. J. 2020. Colostrum: Back to basics with immunoglobulins. J. Anim. Sci. 98:126-132. https://doi.org/10.1093/jas/ skaa142

Genc, M. 2015. Effect Of Some Environmental Factors on Colostrum Quality and Passive Immunity in Brown Swiss and Holstein Cattle. Ph.D. Thesis, Atatürk Uni., Health Sciences Institute, Erzurum.

Gross, J. J., E.C. Kessler, V. Bjerre-Harpoth, C. Dechow, C. R. Baumrucker, \& R. M. Bruckmaier. 2014. Peripartal progesterone and prolactin have little effect on the rapid transport of immunoglobulin G into colostrum of dairy cows. J. Dairy Sci. 97:2923-2931. https://doi.org/10.3168/jds.2013-7795

Gulliksen, S.M., K.I. Lie, L. Sølverød, \& O. Østera. 2008. Risk factors associated with colostrum quality in Norwegian dairy cows. J. Dairy Sci. 91:704-712. https://doi.org/10.3168/ jds.2007-0450

Hoyraz, M., R. Sezer, M. Demirtaş, \& A. Koç. 2015. A Research on colostrum quality and constituents of Holstein-Friesian cows. J. Tralleis Elektron. 4:1-7.

Johnsen, J. F., H. Viljugrein, K. E. Boe, S. M. Gulliksen, A. Beaver, A. M. Grøndahl, T. Sivrtsen, \& C. M. Mejdell. 2019. A cross-sectional study of suckling calves' passive immunity and associations with management routines to ensure colostrum intake on organic dairy farms. Acta Vet. Scand. 61:1-10. https://doi.org/10.1186/s13028-019-0442-8

Kessler, C., G. C. Pistol, R. M. Bruckmaier, \& J. J. Gross. 2020a. Pattern of milk yield and immunoglobulin concentration and factors associated with colostrum quality at the quarter level in dairy cows after parturition. J. Dairy Sci. 103: 965971. https://doi.org/10.3168/jds.2019-17283

Kessler, E. C., R. M. Bruckmaier, \& J. J. Gross. 2020b. Colostrum composition and immunoglobulin G content in dairy and dual-purpose cattle breeds. J. Anim. Sci. 98:skaa 237. https:// doi.org/10.1093/jas/skaa237

Le Cozler, Y., R. Guatteo, E. LeDréan, H. Turban, F. Leboeuf, K. Pecceu, \& J. Guinard-Flament. 2016. IgG1 variations in the colostrum of Holstein dairy cows. Animal 10: 230-237. https://doi.org/10.1017/S1751731115001962

Løkke, M. M., R. Engelbrecht, \& L. Wiking. 2016. Covariance structures of fat and protein influence the estimation of IgG in bovine colostrum. J. Dairy Res. 83:58-66. https://doi. org/10.1017/S0022029915000734

Maunsell, F. P., D. E. Morin, P. D. Constable, W. L. Hurley, I. McCoy, G. C. Kakoma, \& R. E. Isaacson. 1998. Effects of mastitis on the volume and composition of colostrum produced by Holstein cows. J. Dairy Sci. 81:1291-1299. https:// doi.org/10.3168/jds.S0022-0302(98)75691-7

Mayasari, N., G. de Vries Reilingh, M. G. Nieuwland, G. J. Remmelink, H. K. Parmentier, B. Kemp, \& A. T. van Knegsel. 2015. Effect of maternal dry period length on colostrum immunoglobulin content and on natural and specific antibody titers in calves. J. Dairy Sci. 98:3969-3979. https://doi.org/10.3168/jds.2014-8753

Morrill, K. M., E. Conrad, A. Lago, J. Campbell, J. Quigley, \& H. Tyler. 2012. Nationwide evaluation of quality and composition of colostrum on dairy farms in the United States. J. Dairy Sci. 95:3997-4005. https://doi.org/10.3168/ jds.2011-5174

Morrill, K. M., K. E. Robertson, M. M. Spring, A. L. Robinson, \& H. D. Tyler. 2015. Validating a refractometer to evaluate immunoglobulin $\mathrm{G}$ concentration in Jersey colostrum and the effect of multiple freeze-thaw cycles on evaluating colostrum quality. J. Dairy Sci. 98:595-601. https://doi. org/10.3168/jds.2014-8730

Morrow, D. A. 1976. Fat cow syndrome. J. Dairy Sci. 59:16251629. https://doi.org/10.3168/jds.S0022-0302(76)84415-3

Puppel, K., M. Gołębiewski, G. Grodkowski, P. Solarczyk, P. Kostusiak, M. Klopčič, \& T. Sakowski. 2020. Use of somatic cell count as an indicator of colostrum quality. PLoS ONE 15:1-15. https://doi.org/10.1371/journal.pone.0237615

Quigley, J. D., A. Lago, C. Chapman, P. Erickson, \& J. Polo. 2013. Evaluation of the Brix refractometer to estimate immunoglobulin G concentration in bovine colostrum.J. Dairy Sci. 96:1148-1155. https://doi.org/10.3168/jds.2012-5823

Shivley, C. B., J. Lombard, N. Urie, D. Haines, R. Sargent, C. Kopral, T. Earleywine, J. Olson, \& F. Garry. 2018. Pre weaned heifer management on US dairy operations: Part II. Factors associated with colostrum quality and passive transfer status of dairy heifer calves. J. Dairy Sci. 101:91859198. https://doi.org/10.3168/jds.2017-14008

Silva-Del-Río, N., D. Rolle, A. García-Muñoz, S. Rodríguez Jiménez, A. Valldecabres, A. Lago, \& P. Pandey. 2017. Colostrum immunoglobulin G concentration of multiparous Jersey cows at first and second milking is associated with parity, colostrum yield, and time of first milking, and can be estimated with Brix refractometry. J. Dairy Sci. 100:5774-5781. https://doi.org/10.3168/jds.2016-12394

Shoshoni, E., S. Rozen, \& J. J. Doekes. 2014. Effect of a short dry period on milk yield and content, colostrum quality, fertility, and metabolic status of Holstein cows. J. Dairy Sci. 97:2909-2922. https://doi.org/10.3168/jds.2013-7733

Sutter, F., S. Borchardt, G. M. Schuenemann, E. Rauch, M. Erhard, \& W. Heuwieser. 2019. Procedures after calving to improve harvesting of high-quantity and highquality colostrum. J. Dairy Sci. 102: 9370-9381. https://doi. org/10.3168/jds.2019-16524

Turini, L., G. Conte, F. Bonelli, M. Sgorbini, A. Madrigali, \& M. Mele. 2020. The relationship between colostrum quality, passive transfer of immunity and birth and weaning weight in neonatal calves. Livest. Sci. 238:1-4. https://doi. org/10.1016/j.livsci.2020.104033

Verweij, J. J., A. P. Koets, \& S. W. F. Eisenberg. 2014. Effect of continuous milking on immunoglobulin concentrations in bovine colostrum. Vet. Immunol. Immunopathol. 160:225229. https://doi.org/10.1016/j.vetimm.2014.05.008

Zentrich, E., M. Iwersen, M. C. Wiedrich, M. Drillich, \& D. Klein-Jöbstl. 2019. Short communication: Effect of barn climate and management-related factors on bovine colostrum quality. J. Dairy Sci. 102:7453-7458. https://doi. org/10.3168/jds.2018-15645 